\title{
Feeding Habits of Stellifer rastrifer (Perciformes, Sciaenidae) at Guaratuba Mangrove, Parana, Brazil
}

\author{
Paulo de Tarso C. Chaves* and Ana Lúcia Vendel \\ Departamento de Zoologia, UFPR. C.P. 19020, CEP 81531-990, Curitiba, Brasil.
}

\begin{abstract}
Feeding habits of Stellifer rastrifer (Perciformes, Sciaenidae) at Guaratuba mangrove, Parana, Brazil, were studied from February 1996 to February 1997. It was observed that its diet was based on invertebrates, mainly Decapoda non-Brachyura and Polychaeta. In a smaller proportion there were plants, Copepoda, Gammaridea and Mollusca. The level of contribution of each food item changed according to the season and the individual size. Such plasticity in feeding behaviour was similar to that described to some fish populations from other estuaries, and could be an indicator of the high level of instability presented by this kind of ecosystem.
\end{abstract}

Key-words: Feeding habit; Stellifer rastrifer; Sciaenidae; Mangrove; Guaratuba, Parana.

\section{INTRODUCTION}

The "cangulo" or "cangua", Stellifer rastrifer (Jordan, 1889), is distributed from Colombia to the southern Brazil, usually with $200 \mathrm{~mm}$ maximum size, on sand or mud bottoms (Menezes \& Figueiredo, 1980). In the mangrove of the Guaratuba Bay, they form an abundant, sedentary population and spawn during both winter and spring (Chaves \& Vendel, 1997). Their feeding habits, primarily carcinophagous, was related in a large sense by Menezes \& Figueiredo (1980), concerning to the southsouthern coast of Brazil. Based on some facts known about the fish populations at the Guaratuba mangrove (Chaves \& Vendel, 1996; Chaves et al., 1998; Vendel \& Chaves, 1998), it seemed that $S$. rastrifer diet could present some particularities in this region. In fact, Albaret \& Diouf (1994) attributed the large trophical opportunism showed by estuarine fishes to their reduced alimentary specialisation level. The present work describes the $S$. rastrifer feeding habit in order to know the trophical role played by this important fish species in the Guaratuba Bay.

\section{MATERIALS AND METHODS}

Fish were collected monthly from February 1996 to February 1997 using an otter trawl with a $20 \mathrm{~mm}$ mesh at various sites of the mangrove of the Guaratuba Bay $\left(25^{\circ} 52^{\prime} \mathrm{S} ; 48^{\circ} 39^{\prime} \mathrm{W}\right)$, as shown in the map by Chaves \& Vendel (1996; 1997) or Vendel \& Chaves (1998).

After transporting to laboratory - approximately 2 hours - the specimens were weighted and measured (total length). All stomachs were removed in order to evaluate its content. The intensity of feeding was monthly estimated using the mean percentage occurrence of empty and non-empty stomachs (Longhurst, 1957; Juras \& Yamaguti, 1985). The non-empty ones $(n=235)$ were immediately fixed in a $10 \%$ formaline solution.

The items of stomach contents were identified at stereoscopic microscope and the results obtained were analysed by two methods (Hynes, 1950): Frequency of Occurrence (FO), percentage of food-containing stomachs in which the type of food in question occurs; and Number of Points (P), percentage occupied by each item respected to the total contents surface, when measured on a pointed surface. The results derived from these two methods were conjugated by the Preponderance Index (PI), based on Juras \& Yamaguti (1985):

$$
\mathbf{P I}_{\mathrm{i}}=\left(\mathbf{F O}_{\mathrm{i}} \cdot \mathbf{P}_{\mathrm{i}}\right) / \sum_{\mathrm{i}=1 \rightarrow n}\left(\mathbf{F O}_{\mathrm{i}} \cdot \mathbf{P}_{\mathrm{i}}\right) \cdot 100
$$

where ${ }_{i}$ " is each one of the " $n$ " analysed items.

In order to verify a possible influence of the total length of the specimens on the results of feeding habits in each season, a comparative analysis of 
the diet (F.O. data only) according to the size was made by the arrangement of the specimens in 2 groups:

- the "smallest" individuals, with a total length smaller than or equal to the mean length of the sample in the season; and

- the "greatest" individuals, with a total length greater than the mean length of the sample.

The mean length considered was $107 \mathrm{~mm}$ in summer, $128 \mathrm{~mm}$ in autumn, $130 \mathrm{~mm}$ in winter and $139 \mathrm{~mm}$ in spring, always larger than that of the first maturity found in this species (97$95 \mathrm{~mm}$, males and females - Coelho et al., 1985).

\section{RESULTS}

Table 1 shows the number of individuals sampled in each month and their length range. The frequency of non-empty stomachs varied considerably from month to month, from $33 \%$ (September) to $100 \%$ (August). However, no recognisable seasonal cycle in this variation could be seen (Fig. 1).

The organisms from the bulked stomach contents comprised an assortment of crustaceans and other benthic organisms. The highest values of Preponderance Index were obtained for Polychaeta and crustaceans, mainly Decapoda non-Brachyura (shrimps). In smaller number, there were plants, Copepoda, Gammaridea and Mollusca. The less abundant groups found in the stomach contents were fish, Isopoda, Caprellidea and Brachyura (e.g.: Portunidae) (Table 2).

According to the season of sampling, some variations in both the nature and the abundance of the items were registered. In spring, Polychaeta were present in more than $80 \%$ and Mollusca and Gammaridea in more than $40 \%$ of the individuals analysed (Table 2). In summer, Mollusca, Copepoda and Gammaridea presented small values of Frequency of Occurrence but Table 1. Number (n) and total length of the smallest and the largest specimens of $S$. rastrifer whose stomach contents were analyzed each month, at Guaratuba mangrove. TL: total length.

\begin{tabular}{cccc}
\hline MONTH & n & TL $(\mathrm{mm})$ & MEAN $(\mathrm{mm})$ \\
\hline February 96 & 17 & $93-149$ & 122.3 \\
March 96 & 0 & - & - \\
April 96 & 8 & $129-156$ & 143.4 \\
May 96 & 15 & $86-146$ & 112.1 \\
June 96 & 18 & $101-174$ & 115.3 \\
July 96 & 13 & $128-160$ & 140.2 \\
August 96 & 18 & $95-123$ & 108.3 \\
September 96 & 6 & $112-121$ & 116.5 \\
October 96 & 9 & $112-165$ & 139.1 \\
November 96 & 8 & $141-161$ & 150.5 \\
December 96 & 0 & - & - \\
January 97 & 38 & $65-150$ & 121.4 \\
February 97 & 85 & $58-156$ & 92.3 \\
\hline ToTAL & $\mathbf{2 3 5}$ & - & - \\
\hline
\end{tabular}

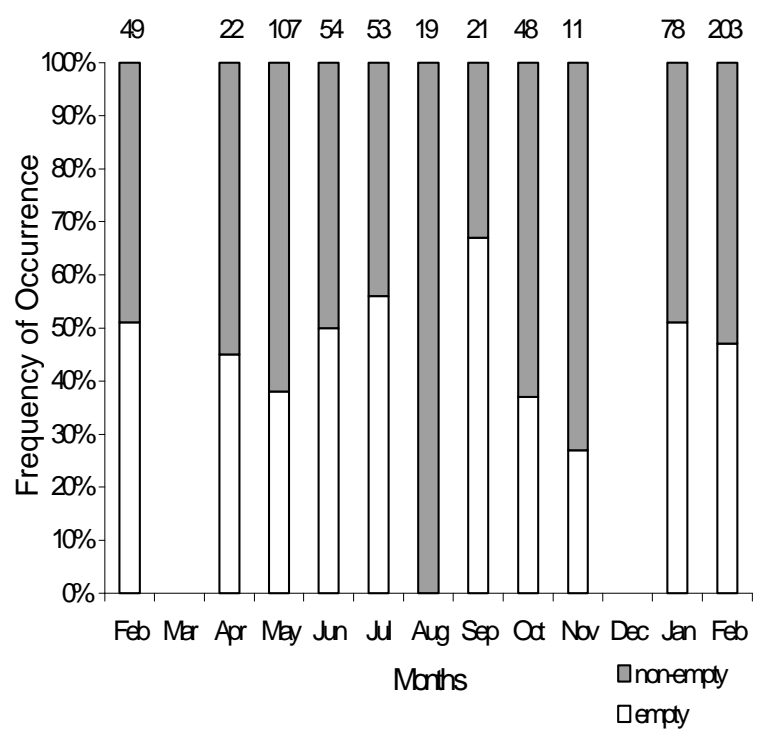

Fig. 1. Monthly proportion of empty and non-empty Fig. 1. Monthly proportion of empty and non-empty stomachs from February 1996 to February 1997. The values above each column indicate the size of the samples (no samples in March and December).

great ones of the Preponderance Index, when compared to the precedent season (Table 2). Decapoda non-Brachyura (e.g.: Caridea and Pennaeidea) were the dominant item also in autumn, however in this season Copepoda reached their greatest abundance (Table 2). Finally, in winter, a relatively small variety of prey categories was found, but all food items were registered in $10 \%$ or more of the stomachs analysed. Plants, present in more than $45 \%$ of 
Table 2. Results of the stomach contents analysis in 235 individuals of $S$. rastrifer from the Guaratuba mangrove, according to the method. Su: summer; A: autumn; W: winter; Sp: spring.

\begin{tabular}{|c|c|c|c|c|c|c|c|c|c|c|c|c|}
\hline \multirow{2}{*}{$\begin{array}{c}\text { METHOD } \\
\text { Item }\end{array}$} & \multicolumn{4}{|c|}{$\begin{array}{c}\text { FREQUENCY OF } \\
\text { OCCURRENCE }(\%) \\
\end{array}$} & \multicolumn{4}{|c|}{$\begin{array}{c}\text { NUMBER OF POINTS } \\
(\%)\end{array}$} & \multicolumn{4}{|c|}{$\begin{array}{c}\text { PREPONDERANCE } \\
\text { INDEX }\end{array}$} \\
\hline & Su & $\mathbf{A}$ & $\mathbf{W}$ & Sp & $\mathrm{Su}$ & $\mathbf{A}$ & $\mathbf{W}$ & Sp & $\mathrm{Su}$ & $\mathbf{A}$ & $\mathbf{W}$ & $\mathrm{Sp}$ \\
\hline Polychaeta & 2.1 & 7.3 & 13.5 & 82.3 & 4.8 & 0.9 & 8.6 & 59.5 & 0.4 & 0.2 & 3.4 & 83.2 \\
\hline Mollusca & 20.0 & & & 41.2 & 11.2 & & & 6.0 & 8.6 & & & 4.2 \\
\hline Decapoda Brachyura & 2.1 & 9.7 & & 5.9 & 5.1 & 6.1 & & 3.9 & 0.4 & 1.4 & & 0.4 \\
\hline Decapoda non-Brachyura & 44.3 & 56.1 & 40.5 & 17.6 & 42.0 & 43.4 & 33.0 & 15.9 & 71.4 & 56.3 & 39.4 & 4.8 \\
\hline Caprellidea & 2.1 & 9.7 & & 11.8 & 1.3 & 2.4 & & 2.1 & 0.1 & 0.5 & & 0.4 \\
\hline Copepoda & 17.1 & 48.8 & 27.0 & 23.5 & 18.7 & 33.3 & 17.6 & 3.7 & 12.3 & 37.6 & 14.0 & 4.5 \\
\hline Gammaridea & 15.7 & 19.5 & 18.9 & 41.2 & 10.0 & 3.6 & 5.29 & 7.6 & 6.0 & 1.6 & 2.9 & 5.3 \\
\hline Isopoda & 0.7 & 4.9 & & & 3.0 & 0.5 & & & 0.1 & 0.1 & & \\
\hline Fish & 4.3 & 4.9 & 10.8 & 5.9 & 0.4 & 3.9 & 4.3 & 1.2 & 0.1 & 0.4 & 1.4 & 0.1 \\
\hline Plants & 2.8 & 14.6 & 45.9 & & 1.0 & 4.4 & 27.7 & & 0.1 & 1.5 & 37.4 & \\
\hline Non-identified material & 5.7 & 9.7 & 13.5 & & 2.5 & 1.3 & 3.7 & & 0.5 & 0.3 & 1.5 & \\
\hline TOTAL & - & - & - & - & 100 & 100 & 100 & 100 & 100 & 100 & 100 & 100 \\
\hline
\end{tabular}

the individuals, reached in winter a level of participation, similar to that presented by Decapoda non-Brachyura (Table 2). Sand and Nematoda were found overall the year, but they were not considered as food item.

The food data according to the size classes revealed that all items integrated the diet of both the "smallest" and the "largest" individuals (Fig. 2). However, overall seasons the "smallest" individuals fed with a higher frequency than the "largest" ones on Polychaeta and Copepoda. An inverse pattern was found with respect to Brachyura and fish (Fig. 2).

\section{DISCUSSION}

The diet of $S$. rastrifer at Guaratuba mangrove, based upon invertebrates, particularly crustaceans, has a similar pattern to that described by the literature concerning to this species (Menezes \& Figueiredo, 1980). However, the temporal analysis indicated variations in the diet according to season, which could be in general associated to the food availability (Zavala-Camin, 1996). In fact, associations between the changes in both dietary items and invertebrates availability were found in many studies (Wakabara et al., 1993; Grosman, 1995), and the seasonal changes that occur at the benthos structure in mangroves (Lana \& Guiss, 1991) were additional evidences in this respect.
The substitution of crustaceans by Polychaeta as the most important food item, detected in $S$. rastrifer in spring, was observed in the same season at Guaratuba in Genidens genidens (Chaves \& Vendel, 1996). This fact probably did not indicate an exceptional concentration of Polychaeta in the mangrove during this season, because in Bairdiella ronchus it was the principal food item in another season, the winter (Vendel \& Chaves, 1998).

As described for other species and milieus (Juras \& Yamaguti, 1985; Edgar \& Shaw, 1995; Zavala-Camin, 1996), differences were found between the largest and the smallest specimens studied. Because from summer to spring the size of the sampled specimens increased gradually, the results that indicate the temporal variations could be associated to the more common lengths each season. Polychaeta and Copepoda are more frequents in the smallest individuals than in the largest ones, while fishes and Brachyura are more frequents in the largest individuals than in the smallest ones. Then, a length size influence could be confirmed by an increase in the participation of the two first items in summer, and of the two others in spring. None of these facts occurred, therefore we can suppose that the size composition of the individuals was not the dominant factor determining the results obtained.

It was observed that the food nature was not the only attribute that changed seasonally, but also the level of participation of the principal items 

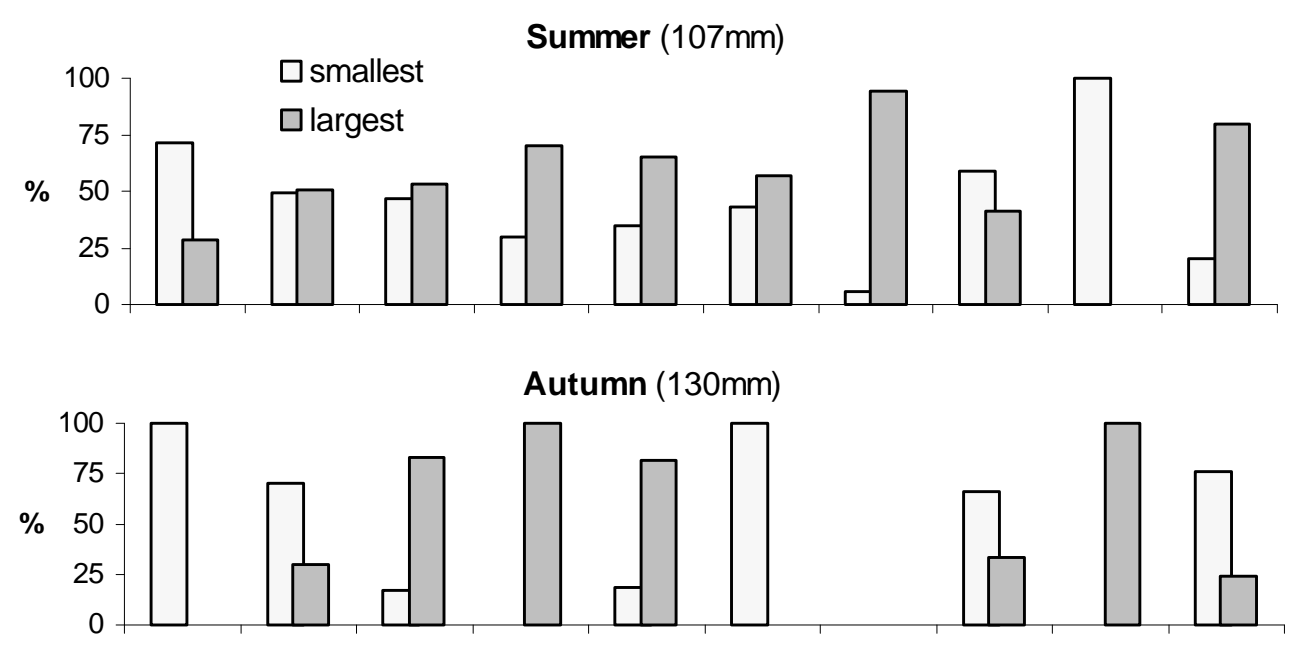

Winter (128mm)

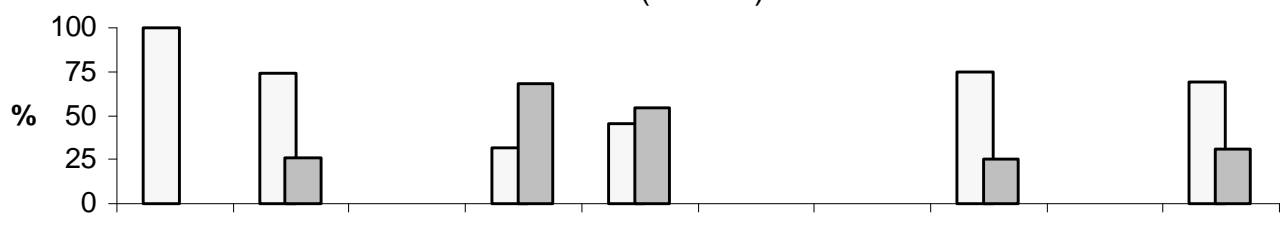

Spring (139mm)

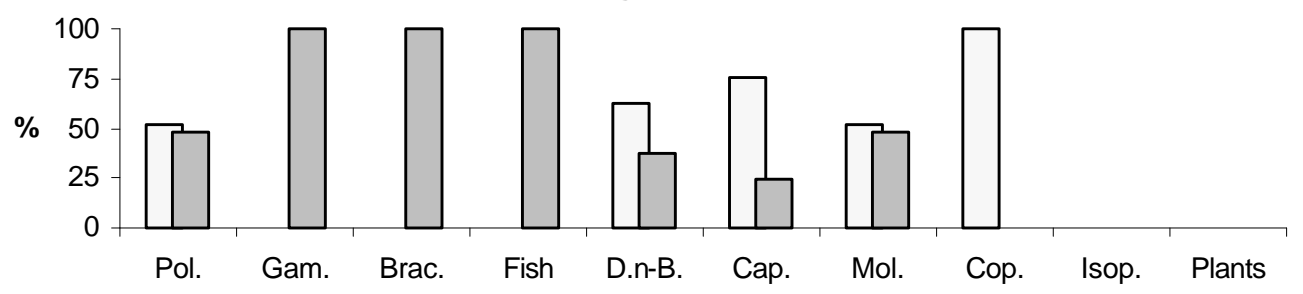

Fig. 2 - Seasonal percentage of occurrence of each dietary category in the "smallest" and the "largest" specimens (limit indicated) of S. rastrifer at Guaratuba mangrove. Pol.: Polychaeta; Gam.: Gammaridea; Brac.: Brachyura;

D.n-B.: Decapoda non-Brachyura; Cap.: Caprellidea; Mol.: Mollusca; Cop.: Copepoda; Isop.: Isopoda.

with respect to the secondary ones. So, in spring the values of PI could reach $83 \%$ (Polychaeta), while in winter any PI reached values higher than $40 \%$. In spring, although some items are relatively important, diet was based merely on Polychaeta; in winter, it is based on three items: Decapoda non-Brachyura, Copepoda and plants. In summer and autumn, some intermediary patterns were observed.

A global interpretation, independent of the size classes and comparative with other fish populations of the Guaratuba mangrove, revealed a close similarity between the diet of $S$. rastrifer and that of the flatfish Achirus lineatus (Chaves \& Serenato, 1998). In both, Decapoda non-Brachyura and Polychaeta were the principal items. Other Sciaenidae of this mangrove fed mainly fish and crustaceans (Isopisthus parvipinnis - Chaves et al., 1998) or Decapoda non-Brachyura and Polychaeta (Bairdiella ronchus - Vendel \& Chaves, 1998).

The monthly analysis of the empty and nonempty stomachs frequencies showed fairly steady rate of feeding, with no detectable seasonal fluctuation. On the other hand, Chaves et al. (1998) noted that in I. parvipinnis (Sciaenidae) from the same mangrove the percentage of empty stomachs increased gradually from summer to winter. The frequency of empty stomachs found in each species during the total period of study were $60 \%$ in $I$. parvipinnis and $35 \%$ in $S$. rastrifer. These results differed from those recorded by Longhurst (1957) in another estuarine system, 
where the food intake of ichthyophagous species was lower than those of species whose diet was based on benthic invertebrates.

\section{ACKNOWLEDGMENTS}

Communication 1024 of the Department of Zoology - UFPR. We are very grateful to the CNPq and FUNPAR for financial grants; for the identification of food organisms we have to thank Janete Dubiaski Silva (UFPR) and other colleagues; Michel Jegu (ORSTOM), Laurence Blanc (Université Montpellier II) and Maria Rosa Quintans Lopez (UEPG) have provided important suggestions to the manuscript.

\section{RESUMO}

A alimentação do cangulo ou canguá, Stellifer rastrifer, foi estudada no manguezal da Baía de Guaratuba entre fevereiro 1996 e fevereiro 1997. Constatou-se que a dieta está baseada em invertebrados, sobretudo Decapoda Brachyura e Polychaeta. Secundariamente, registram-se vegetais superiores, Copepoda, Gammaridea e Mollusca. O grau de participação dos itens varia com a estação e o tamanho dos indivíduos. Tal plasticidade no hábito alimentar, também conhecida em outras populações de peixes estuarinos, pode ser considerada como mais um indicador do grau de instabilidade encontrado nestes ambientes.

\section{REFERENCES}

Albaret, J. J. \& Diouf, P. S. (1994), Diversité des poissons des lagunes et des estuaires ouest-africains. Ann. Mus. R. Afr. Centr., Zool., 275, 165-177.

Chaves, P.T.C. \& Vendel, A.L. (1996), Aspectos da alimentação de Genidens genidens (Valenciennes) (Siluriformes, Ariidae) na Baía de Guaratuba, Paraná. Revta bras. Zool., 13(3), 669-75.

Chaves, P.T.C. \& Vendel, A.L. (1997), Reprodução de Stellifer rastrifer (Jordan) (Teleostei, Sciaenidae) na Baía de Guaratuba, Paraná, Brasil. Revta bras. Zool., 14(1), 8189.
Chaves, P.T.C.; Rickli, A.; Bouchereau, J.-L. (1998), Stratégie d'occupation de la mangrove de la baie de Guaratuba (Brésil) par le Sciaenidae prédateur Isopisthus parvipinnis (Teleostei, Pisces). Cahiers de Biologie Marine, Roscoff (França), 39(1), 63-71.

Chaves, P.T.C. \& Serenato, A. (1998), Diversidade de dietas na assembléia de linguados (Teleostei, Pleuronectiformes) no manguezal da Baía de Guaratuba, Paraná, Brasil. Revista Brasileira de Oceanografia, 46(1), 61-68.

Coelho, J.A.P.; Graça-Lopes, R.; Rodrigues, E.S.; Puzzi, A. (1985), Relação pesocomprimento e tamanho de início de primeira maturação gonadal para o Sciaenidae Stellifer rastrifer (Jordan, 1889) no litoral do Estado de São Paulo. B. Inst. Pesca, 12(2), 99-107.

Edgar, G.J. \& Shaw, C. (1995), The production and trophic ecology of shallow-water fish assemblages in southern Australia. II. Diets of fishes and trophic relationships between fishes and benthos at Western Port, Victoria. J. Exp. Mar. Biol. Ecol., 194, 83-106.

Grosman, M.F. (1995), Seasonal variation in the silverside fish (Odonthestes bonariensis) diet. Revta Assoc. Cienc. Nat. Litor., St Tomé, 26(1), 9-18.

Hynes, H.B.N. (1950), The food of fresh-water sticklebacks (Gasterosteus aculeatus and Pigosteus pungitius) with a review of methods used in studies of food of fishes. $J$. Anim. Ecol., 19(1), 36-57.

Juras, A.A. \& Yamaguti, N. (1985), Food and feeding habits of king weakfish, Macrodon ancylodon (Bloch \& Schneider, 1801) caught in the southern coast of Brazil. Bolm Inst. oceanogr., São Paulo, 33(2), 149-157.

Lana, P.C. \& Guiss, C. (1991), Influence of Spartina alterniflora on structure and temporal variability of macrobenthic associations in tidal flat of Paranagua Bay (Southeastern Brazil). Mar. Ecol. Progr. Ser., 73(2-3), 231-44.

Longhurst, A. R. (1957), The food of the demersal fish of a West African estuary. $J$. Anim. Ecol., 26, 369-387.

Menezes, N.A. \& Figueiredo, J.L. (1980), Manual de Peixes Marinhos do Sudeste do Brasil. Teleostei (3). Museu de Zoologia, Universidade de São Paulo, Brasil. 96p. 
Vendel, A.L. \& Chaves, P.T.C. (1998), Alimentação de Bairdiella ronchus (Cuvier) (Perciformes, Sciaenidae) na Baía de Guaratuba, Paraná, Brasil. Revta bras. Zool., 15(2), 297-305.

Wakabara, Y.; Tararam, A.S.; Flynn, M.N. (1993), Importance of the macrofauna for the feeding of young fish species from infralittoral of Arrozal-Cananeia lagoon estuarine region $\left(25^{\circ} 02^{\prime} \mathrm{S}-47^{\circ} 56^{\prime} \mathrm{W}\right)$ - Brazil.
Bolm Inst. Oceanogr., S Paulo, 41(1/2), 3952.

Zavala-Camin, L.A. (1996), Introdução aos Estudos sobre Alimentação Natural em Peixes. Editora da Universidade Estadual de Maringá, Maringá, Brasil. 129p.

Received: June 06, 1998; Revised: June 22, 1998; Accepted: June 29, 1998. 